\title{
IMPLEMENTASI METODE INQUIRY LEARNING DALAM PERMAINAN ULAR TANGGA PADA PELAJARAN TAUHID DI KELAS 3 MADRASAH DINIYAH DI PONPES NGALAH
}

\author{
Universitas Yudharta Pasuruan, Jawa Timur, Indonesia \\ Kholishotul Amaliyah, Wiwin Fachrudin Yusuf \\ amaliyahlibek@gmail.com, maswiwinfachrudin@yudharta.ac.id
}

\begin{abstract}
method Inquiry Learning is a teaching that specifies students to solve problems so that they gain knowledge, experience, expertise, and skills. Why use the method Inquiry Learning, because it is seen from the class situation, in the third grade students on average do not pay attention to the teacher who is explaining the lesson in front. In the class there are also students when they are tired they are sleepy. So the teacher invites students to learn while playing. Judging from these problems, the researcher takes the formulation of the problem (1) how to implement theMethod Inquiry Learning in the Snake and Ladder Game Tauhid Lessons in Class 3 Madrasah Diniyah at Ngalah Ponpes (2) what are the strengths and weaknesses of the method inquiry learning at Madrasah Diniyah in Ngalah Ponpes.
\end{abstract}

This research use descriptive qualitative approach. The research findings obtained are based on the results of observations, interviews, and documentation. There are several steps that must be done in analyzing data in qualitative research. The first is data reduction, the second is data exposure, the third is the conclusion. To check the validity of the findings, the researcher used triangulation, where triangulation is a technique of checking the validity of data by using various sources from outside the data as comparison material. The results of the study of students respond to what the teacher says. Students are also more enthusiastic in the teaching and learning process. The advantages of implementing the method Inquiry Learning in the game of snakes and ladders in tauhid lessons in grade 3 at Madrasah Diniyah Ponpes Ngalah are as follows: 1) Students can learn to think critically in solving a problem, 2) Students are also taught about compact life and family life, 3) Make it easier for students to repeat lessons that have been taught, 4) Increase students' insight. The weaknesses of the implementation of the method Inquiry Learning in the game of snakes and ladders in tauhid lessons in grade 3 at Madrasah Diniyah Ponpes Ngalah are as follows: 1) Students are still choosing their respective group friends, 2) Lack of group work, 3) One or two children are still do not want to participate in teaching and learning activities, 4) There are some students who cannot answer the questions on the game. 


\section{A. PENDAHULUAN}

Pendidikan dalam kamus besar bahasa Indonesia merupakan proses perubahan sikap dan tata laku seseorang atau sekelompok orang dalam usaha mendewasakan manusia melalui upaya pengajaran dan pelatihan. ${ }^{1}$ Pendidikan merupakan modal utama bagi suatu bangsa dalam upaya meningkatkan kualitas sumberdaya manusia yang dimilikinya. Sumber daya manusia yang berkualitas akan mampu memproses sumber daya alam dan memberi layanan secara berguna dan tepat untuk meningkatkan kesejahteraan masyarakat. Oleh karena itu, hampir semua bangsa berusaha meningkatkan mutu pendidikan yang dimilikinya, termasuk Indonesia. ${ }^{2}$ Dalam peningkatan mutu pendidikan tersebut salah satunya adalah dengan upaya peningkatan mutu pembelajaran.

Pembelajaran adalah suatu upaya yang dilakukan guru secara sengaja dengan tujuan menyampaikan ilmu pengetahuan, dengan cara menciptakan suatu sistem lingkungan belajar dengan berbagai metode sehingga peserta didik dapat melakukan kegiatan belajar secara optimal. ${ }^{3}$ Salahsatu upaya yang dilakukan dalam menciptakan suasana pembelajaran yang kondusif dan menyenangkan dengan menggunakan metode pembelajaran yang lebih bervariatif. Sebelum dijelaskan lebih luas, dalam suatu proses belajar mengajar ada dua unsur yang amat penting yang pertama metode mengajar dan yang kedua media pengajaran. Kedua aspek ini saling berkaitan. Pemilihan salahsatu metode mengajar tentu akan mempengaruhi jenis media pengajaran yang sesuai, meskipun masih ada berbagai aspek lain yang harus diperhatikan dalam memilih media, antara lain tujuan pengajaran, jenis tugas dan

\footnotetext{
${ }^{1}$ Sugiharto, Dkk, "Psikologi Pendidikan". Yogyakarta: UNY Press, Hal. 3

${ }^{2}$ Tri Lestari, Hari Wujoso, Nunuk Suryani, "Pengarub Metode Pembelajaran Ceramah Plus Dan Metode Drill Terbadap Motivasi Belajar Dan Hasil Belajar Pada Kompentensi Dasar Efisiensi Penggunaan Tempat Tidur Rumah Sakit”. Vol. 7 No. 1, Juni 2017, Hal. 17 ${ }^{3}$ Askhabul kirom. "Peran Guru Dan Peserta Didik Dalam Proses Pembelajaran Berbasis Multikultural”. Vol. 3 no. 1. Hal. 69
} 
respon peserta didik yang diharapkan oleh guru. ${ }^{4}$ Dalam penelitian ini metode inquiry learning digunakan sebagai alternative dalam pembelajaran tersebut.

Metode Inquiry learning adalah metode yang memberi kesempatan kepada siswa untuk terlibat secara aktif dalam proses pembelajaran melalui percobaan maupun eksperimen sehingga melatih siswa berkreativitas dan berpikir kritis untuk menemukan sendiri suatu pengetahuan yang pada akhirnya mampu menggunakan pengetahuannya tersebut dalam memecahkan masalah yang dihadapi. Siswa benar-benar ditempatkan sebagai subjek yang belajar. ${ }^{5}$ Supaya peserta didik lebih semangat untuk berpikir guru menggunakan media permainan ular tangga. Dengan bermain peserta didik bisa lebih antusias dalam proses pembelajarannya.

Permainan ular tangga adalah salahsatu jenis permainan tradisional yang mendunia. Permainan ini tidak hanya berlaku di negara kita saja, tetapi juga diberbagai negara lain di dunia. Permainan ini merupakan jenis permainan kelompok, melibatkan beberapa orang dan tidak dapat digunakan secara individu. Secara psikologis, ular tangga terbukti dapat meningkatkan kemampuan anak-anak untuk berinteraksi dengan kehidupan sosial. Berbeda dengan permainan berbasis media elektronik yang mengedepankan permainan individu, dimana anak-anak akan berkonsentrasi untuk sepenuhnya berinteraksi dengan media elektronik seperti komputer, video game atau play station. Para pakar psikologi

\footnotetext{
${ }^{4}$ Wiwin Fachrudin Yusuf \& Firdausi Nuzulia. "Media Limbah Botol Untuk

Meningkatkan Pembelajaran PAI Di RA Miftabul Khoir I Karangrejo Purwosari”. Vol. 1 No. 1, 2016, Hal. 123

${ }^{5}$ Abdul Karim, "Peningkatan Hasil Belajar Pada Mata Diklat Menginstalasi Sistem Operasi Berbasis Gui Menggunakan Metode Inquiry Pada Siswa Kelas X SMK Negeri 2 Takalar". Vol. 4. No 2, Juli 2016, Hal. 73
} 
menyebutkan, bahwa permainan tradisional cenderung lebih menguntungkan dibandingkan permainan melalui media elektronik. ${ }^{6}$

Dari penjelasan di atas bisa disimpulkan bahwa dalam mengelola kelas itu harus semenarik mungkin karena kalau kelas monoton peserta didik akan jenuh. Biasanya waktu proses belajar mengajar berlangsung di Madrasah Diniyah Ponpes Ngalah peserta didik kebanyakan mengantuk dan ada sebagian kecil peserta didik bilang gurunya tidak asyik jadi ke peserta didik ditinggal tidur atau bicara sendiri dengan teman sebangkunya. Untuk menanggulangi permasalahan seperti ini guru harus memberikan materi pelajaran semenarik mungkin. Seperti peserta didik diajak bermain bersama supaya tidak jenuh dan setiap peserta didik harus aktif, itu bisa menanggulangi peserta didik di Madrasah Diniyah Ponpes Ngalah mengantuk, jika peserta didik yang aktif cuma beberapa orang tidak semuanya maka yang tidak aktif itu akan mengantuk.

Di Madrasah Diniyah Ponpes Ngalah terdapat sebagian peserta didik yang tidur. Ini sebuah tugas yang harus dilakukan oleh guru-guru di Madrasah Diniyah Ponpes Ngalah bagaimana peserta didik bisa memperhatikan guru yang sedang menjelaskan didepan. Berangkat dari permasalahan tersebut dapat dirumuskan dalam beberapa, pertama bagaimana implementasi metode Inquiry Learning dalam permainan ular tangga pada pelajaran tauhid di kelas 3 Madrasah Diniyah Pondok Pesantren Ngalah, kedua apa saja kelebihan dan kelemahan dari metode Inquiry Learning di Madrasah Diniyah Pondok Pesantren Ngalah. Proses pembelajarannya hari pertama guru mejelaskan materi-materi tauhid yang akan diuji besok, supaya peserta didik bisa belajar di kamarnya masingmasing. pada hari pertama juga guru membagi kelompok permainan ular tangganya. Hari kedua guru menjelaskan peraturan permainannya kalau peserta didik sudah paham cara bermainnya baru dimulai permainannya. Dalam permainan tersebut terdapat soal dan hadiah. Kelompok siapa

\footnotetext{
${ }^{6}$ Rahina Nugrahani, "Media Pembelajaran Berbasis Visual Berbentuk Permainan Ular Tangga Untuk. Meningkatkan Kualitas Belajar Mengajar Di Sekolab Dasar”. Vol. 36. No. 1, Juni 2007, Hal. 36
} 
yang sampai di finish terlebih dahulu maka kelompok tersebut yang menang.

\section{B. METODOLOGI}

Penelitian ini menggunakan pendekatan kualitatif yang jenis penelitiannya bersifat deskriptif. Penelitian kualitatif adalah riset yang bersifat deskriptif dan cenderung menggunakan analisis dengan pendekatan induktif. $^{7} \quad$ Penelitian ini menghasilkan data deskriptif berupa kata-kata yang berhubungan dengan implementasi metode Inquiry Learning dalam permainan ular tangga pada pelajaran tauhid di kelas 3 Madrasah Diniyah Pondok Pesantren Ngalah. Dalam metode kualitatif juga memiliki ciri, ciri penelitian kualitatif lebih menekankan realitas sosial sebagai suatu yang utuh, komplek, dinamis, dan bersifat interaktif untuk meneliti kondisi obyek yang alamiah. Data yang diperoleh dapat berbentuk kata, kalimat, skema atau gambar. ${ }^{8}$

Prosedur pengumpulan data ini dilakukan sesuai dengan hasil analisis dan hasil informasi lainnya. Dalam pengumpulan data ada beberapa metode yang pertama yaitu observasi: Observasi merupakan salahsatu teknik untuk pengumpulan data, dan observasi juga digunakan untuk memperoleh informasi sebagaimana tujuan utama penelitian. ${ }^{9}$ Pengamatan ini digunakan peneliti untuk mengetahui keadaan di lokasi tersebut. Dengan mengetahui keadaan, peneliti bisa dengan mudah untuk mengetahui keadaan di kelas juga mengetahui respon peserta didik dalam pembelajaran ini, yang kedua wawancara: Wawancara adalah suatu proses yang dibicarakan oleh responden dan pewawancara, bagaimana mereka berbicara satu sama lain. ${ }^{10}$ Wawancara ini digunakan peneliti untuk mendapatkan informasi dan data yang akan menjadi fokus

\footnotetext{
${ }^{7}$ Rukin. Metodologi Penelitian kualitatif, (Takalar: Yayasan Ahmar Cendekia Indonesia. 2019). Hal. 6

${ }^{8}$ Sugiyono. Metode penelitian administrasi. (Yogyakarta: LkiS 2008). Hal. 7

${ }^{9}$ Rulam Ahmadi. Metodologi penelitian kualitatif, (Yogyakarta: Ar-Ruzz Media, 2016). Hal. 161

${ }^{10}$ Ibid, 2016. Hal. 120
} 
penelitian yaitu implementasi metode Inquiry Learning dalam permainan ular tangga pada pelajaran tauhid di kelas 3 Madrasah Diniyah Pondok Pesantren Ngalah. Dan peneliti juga menanyakan apa saja kelebihan dan kekurangan dalam menerapkan metode Inquiry Learning dalam permainan ular tangga pada pelajaran tauhid di kelas 3 Madrasah Diniyah Pondok Pesantren Ngalah. Dan yang ketiga dokumentasi: Dokumentasi adalah proses pengumpulan data mengacu pada bahan seperti fotografi, video, film, memo dan sejenisnya. Juga sebagai bagian dari sumber utamanya yaitu observasi dan wawancara. ${ }^{11}$ Dokumentasi ini dilakukan pada saat observasi, wawancara, dan proses dilakukan kegiatan implementasi metode Inquiry Learning dalam permainan ular tangga pada pelajaran tauhid di kelas 3 Madrasah Diniyah Pondok Pesantren Ngalah dan dokumentasi lainnya yang merasa penting dan dibutuhkan. Dokumentasi juga sebagai penguat/pendukung dari fokus penelitian.

Dalam analisis data ada beberapa tahapan yang harus dikerjakan dalam menganalisis data penelitian kualitatif. Yang pertama reduksi data, yang kedua paparan data, yang ketiga kesimpulan. Untuk mengecek keabsahan temuan peneliti menggunakan triangulasi, dimana triangulasi adalah teknik pemeriksaan keabsahan data dengan menggunakan berbagai sumber dari luar data sebagai bahan perbandingan.

\section{HASIL DAN PEMBAHASAN}

\section{Implementasi Metode Inquiry Learning Dalam Permainan Ular Tangga} Pada Pelajaran Tauhid Di Kelas 3 Madrasah Diniyah Ponpes Ngalah

Sesuai dengan penelitian yang sudah dilakukan dan data yang sudah diperoleh, Implementasi Metode Inquiry Learning Dalam Permainan Ular Tangga Pada Pelajaran Tauhid Di Kelas 3 Madrasah Diniyah Ponpes Ngalah itu merupakan sebuah metode dan model pembelajaran yang sudah cukup lama digunakan dalam kelas 3 tersebut. Dengan menggunakan metode Inquiry Learning ini anak menjadi semangat dan

${ }^{11}$ Ibid, 2016. Hal. 179 
tidak mengantuk lagi. Menggunakan metode Inquiry Learning ini juga untuk menanggulangi monoton dalam kelas, dimana peserta didik cuma duduk manis di tempatnya tidak memperhatikan guru di depan yang sedang menjelaskan pelajaran. Metode mengajar yang baik adalah metode yang dapat menumbuhkan kegiatan belajar bagi pelajar, upaya guru dalam memilih metode yang baik merupakan upaya yang paling penting atau pendidikan yang menjadi tanggung jawabnya. ${ }^{12}$ Dalam penelitian ini metode Inquiry Learning digunakan sebagai alternative dalam pembelajaran tersebut.

Metode Inquiry learning adalah metode yang memberi kesempatan kepada siswa untuk terlibat secara aktif dalam proses pembelajaran melalui percobaan maupun eksperimen sehingga melatih siswa berkreativitas dan berpikir kritis untuk menemukan sendiri suatu pengetahuan yang pada akhirnya mampu menggunakan pengetahuannya tersebut dalam memecahkan masalah yang dihadapi. Siswa benar-benar ditempatkan sebagai subjek yang belajar. Pembelajaran Inquiry learning dirancang untuk mengajak siswa secara langsung dalam proses ilmiah dengan waktu yang relatif singkat. Hasil penelitian Schlenker, dalam Joyce dan Weil, menunjukkan bahwa latihan Inquiry learning dapat meningkatkan pengetahuan, produktif dalam berpikir kreatif dan peserta didik menjadi terampil dalam memperoleh dan menganalisis informasi.

Metode pembelajaran Inquiry Learning merupakan kegiatan pembelajaran yang melibatkan secara maksimal seluruh kemampuan peserta didik untuk mencari dan menyelidiki sesuatu secara sistematis, kritis dan logis sehingga mereka dapat merumuskan sendiri temuannya. ${ }^{13}$ Dari pengertian diatas, dapat disimpulkan bahwa dalam pembelajaran harus ada teknik-teknik yang menarik supaya dalam proses belajar

\footnotetext{
${ }^{12}$ Wiwin Fachrudin Yusuf \& Layliyatul Masruroh. "Metode Permainan Tusuk Kata Dalam Meningkatkan Prestasi Belajar Ilmu Tajwid Di Madrasah Diniyah Miftabul Ulum Tutur Pasuruan”. Vol. 1 No. 2, 2016. Hal. 322

${ }^{13}$ Wiwin Fachrudin Yusuf. "Implementasi Kurikulum 2013 (K-13) Pada Mata Pelajaran Pendidikan Agama Islam Sekolah Dasar (SD) “. Vol. 3 No. 1, Juni 2018. Hal. 269
} 
mengajar berjalan dengan baik. Seperti menggunakan metode Inquiry learning ini setiap peserta didik terlibat dalam proses pembelajaran. Jadi peserta didik lebih aktif, kreatif, dan berfikir kritis. Dengan ini peserta didik juga diajarkan bagaimana memecahkan masalah dengan baik. Disini menggunakan pendekatan Pendekatan Inquiry terbimbing adalah pendekatan saat guru membimbing peserta didik melakukan kegiatan dengan memberi pertanyaan awal dan mengarahkan kepada suatu diskusi. Guru pun mempunyai peran aktif dalam menentukan permasalahan dan tahap-tahap pemecahannya. Pendekatan Inquiry terbimbing digunakan bagi peserta didik yang kurang berpengalaman belajar dengan pendekatan Inquiry. Dengan pendekatan ini, peserta didik belajar lebih berorientasi kepada bimbingan dan petunjuk dari guru, sehingga ia mampu memahami konsep-konsep pelajaran. Pada pendekatan ini, peserta didik akan dihadapkan kepada tugas-tugas yang relevan untuk diselesaikan, baik melalui tugas kelompok maupun individual, agar dapat menyelesaikan masalahnya dan menarik beberapa kesimpulan sendiri. Pada dasarnya, selama proses belajar peserta didik akan memperoleh pedoman sesuai dengan yang diperlukan. Pada tahap awal, guru banyak memberikan bimbingan. Kemudian, pada tahap-tahap berikutnya bimbingan tersebut dikurangi, sehingga peserta didik mampu melakukan proses Inquiry secara mandiri. Bimbingan yang diberikan dapat berupa pertanyaan-pertanyaan dan diskusi multiarah yang menggiring peserta didik agar bisa memahami konsep pelajaran. Selain itu, bimbingan dapat pula diberikan melalui lembar kerja peserta didik yang terstruktur. Selama berlangsungnya proses belajar mengajar, guru harus memantau kelompok diskusi peserta didik, sehingga guru sanggup memberikan petunjuk-petunjuk kepada peserta didik.

Karakteristik metode Inquiry Learning menurut Garton, Janeta adalah sebagai berikut: Driving question or problem, Interdisciplinary focus, Authentic investigation, Production of artifacts andex hibits, Collaboration inquiry learning. Mengorganisasikan pengajaran seputar penemuan dan memecahkan masalah yang penting secara sosial dan bermakna secara 
personal bagi peserta didik. Masalah yang investigasi dipilih karena solusinya menuntut peserta didik untuk menggali banyak subjek. Investigasi autentik yang berusaha menemukan solusi real untuk masalah real. Peserta didik harus menganalisis dan menetapkan masalahnya, mengembangkan hipotesis dan membuat prediksi, mengumpulkan dan menganalisis informasi, melaksanakan eksperimen, membuat refrensi, dan menarik kesimpulan. Sifat-sifat atau karakteristik yang ingin dimunculkan dari para peserta didik dalam lingkungan Inquiry Learning ini, menurut Neil Postman yang ditulis kembali oleh Wagiran adalah: Percaya diri terhadap kemampuan belajar, Senang saat berusaha memecahkan masalah, Percaya pada penilaian sendiri dan tidak sekedar bergantung pada penilaian orang lain maupun lingkungan, Tidak takut salah, Tidak ragu dalam menjawab, Fleksibilitas pandangan, Menghargai fakta dan mampu membedakan antara fakta dan opini. ${ }^{14}$ Dalam penelitian ini ada beberapa langkah-langkah, di bawah ini adalah langkah-langkahnya:

a. Fase 1 orientasi

Langkah orientasi adalah langkah dimana guru membina peserta didik supaya merespon. Dalam langkah ini juga guru mencairkan suasana yang awalnya tidak ada yang merespon menjadi banyak yang merespon.

b. Fase 2 merumuskan masalah

Langkah merumuskan masalah merupakan langkah membawa peserta didik kesuatu persoalan yang mengandung tanda tanya. Seperti guru memberi pertanyaan yang bersangkutan dengan materi tauhid. Ada berapa sifat allah? Setelah memberi pertanyaan guru menyuruh peserta didik untuk mencari jawabannya di kelas maupun dikamar masing-masing.

c. Fase 3 merumuskan hipotesis

Langkah hipotesis merupakan jawaban sementara dari suatu permasalahan yang sedang dibahas. Guru memberi pertanyaan

\footnotetext{
${ }^{14}$ Syamsidah, Ratnawati. Panduan model inquiry learning (Yogyakarta: CV BUDI UTAMA 2020). Hal. 5
} 
kepeserta didik pasti disitu peserta didik langsung menjawab supaya jawabannya lebih kuat guru memberi tugas kepeserta didik untuk mencari refrensi lagi dibuku lain atau kitab lain yang membahas tentang sifat allah.

d. Fase 4 mengumpulkan data

Langkah mengumpulkan data adalah mengumpulkan informasi atau pendapat dari ulama-ulama. Tugas yang diberikan guru di kelas waktu hari pertama disuruh untuk mencari sumber dari kitab lain itu dikumpulkan atau di presentasikan. Dalam pengumpulan data peserta didik disuruh menggunakan potensi berfikirnya.

e. Fase 5 menguji hipotesis

Langkah menguji hipotesis adalah langkah yang menentukan jawaban yang dianggap benar dan sesuai dengan refrensi yang ada. Guru juga mengarahkan mana yang salah mana yang benar.

f. Fase 6 merumuskan kesimpulan

Langkah merumuskan kesimpulan adalah menggambarkan temuan yang didapatkan dari hasil pengujian hipotesis. Untuk mencapai kesimpulan guru harus menunjukkan kepeserta didik mana jawaban yang benar.

Memang sebuah keharusan bagi seorang guru untuk menciptakan suasana pembelajaran dan meningkatkan prestasi belajar peserta didik dengan baik. Proses belajar merupakan suatu kegiatan guru untuk menumbuhkan proses belajar mengajar yang efektif, meliputi: tujuan pengajaran, pengaturan penggunaan waktu luang, pengaturan ruang dan alat kelengkapan pelajaran di kelas, serta pengelompokan siswa dalam pembelajaran. ${ }^{15}$ Dalam hal ini cara guru menumbuhkan suatu proses belajar mengajar ialah dengan suatu permainan. Disini guru mengambil

\footnotetext{
${ }^{15}$ M. Anang Sholikhudin, Halimatus Sa'diyah, "Model Pengelolaan Kelas Dalam Pembelajaran PAI Di SD Riyadlul Arkham Tembong Plintaban Pandaan”. Vol. 2. No. 2, Juni 2017, hal. 293
} 
permainan ular tangga, permainan ular tangga termasuk permainan yang digemari peserta didik.

Permainan ular tangga adalah salahsatu jenis permainan tradisional yang mendunia. Permainan ini merupakan jenis permainan kelompok, melibatkan beberapa orang dan tidak dapat digunakan secara individu. Secara psikologis, ular tangga terbukti dapat meningkatkan kemampuan peserta didik dalam berinteraksi dengan sekitarnya. ${ }^{16}$ Permainan ular tangga merupakan salahsatu jenis permainan yang sering dimainkan oleh anak-anak. Permainan ini dimainkan oleh dua anak atau lebih dan ini dapat melatih anak untuk berkompetisi. Selain itu, permainan ular tangga dapat melatih anak untuk bekerja sama serta melatih anak bertindak sportif. ${ }^{17}$ Dari pengertian di atas, dapat disimpulkan bahwa dalam pembelajaran suasana harus menyenangkan supaya peserta didik memahami mata pelajaran yang diberikan. Dengan suasana yang menyenangkan guru dapat mencapai tujuan pembelajaran. Suatu keharusan bagi seorang guru untuk mendidik peserta didik dengan baik dan menyanangkan. Dalam proses belajar mengajar jika dalam ruangan tersebut monoton, maka dalam proses belajar mengajar tidak efektif. Jadi seorang guru harus berusaha mencari cara bagaimana memecahkan suasana tersebut. Dengan ditemani permainan, proses belajar mengajar akan lebih menyenangkan.

Karakteristik permainan ular tangga, dimana permainan ini memiliki daya tarik bagi peserta didik, menyenangkan untuk dilakukan, dan meningkatkan sosialisasi anak dengan teman sebayanya. Selanjutnya, pendapat Francisca dalam jurnal yang ditulis oleh Intan Yuvitasari mengenai permainan ular tangga yaitu: Permainan papan yang terbuat di atas media dua dimensi. Permainan ular tangga merupakan permainan

\footnotetext{
${ }^{16}$ Rahina Nugrahani, "Media Pembelajaran Berbasis Visual Berbentuk Permainan Ular Tangga Untuk. Meningkatkan Kualitas Belajar Mengajar Di Sekolah Dasar". Vol. 36. No. 1, Juni 2007, hal. 36

${ }^{17}$ Febryna Widowati, Mulyani, "Penggunaan Media Ular Tangga Untuk Meningkatkan Hasil Belajar Siswa Pada Tema Hiburan”. Vol. 02. No. 01, 2014, hal. 2
} 
anak-anak berbentuk papan yang dimainkan oleh dua orang atau lebih. Papan permainan dibagi dalam kotak-kotak kecil, sejumlah ular atau tangga digambar di beberapa kotak yang menghubungkannya dengan kotak lain. Pernyataan tersebut menjelaskan bahwa permainan ular tangga merupakan media dua dimensi yang diperuntukkan kepada anakanak dan memiliki ciri-ciri terdapat kotak-kotak kecil, ular dan tangga. Diharapkan dengan permainan tersebut akan berdampak positif terhadap perkembangan peserta didik.

Memang dalam pembelajaran guru harus melakukan yang terbaik buat peserta didiknya supaya apa yang diberikan maksimal dan mencapai apa yang ditujuh. Diterapkannya Inquiry learning ini tidak hanya 1 sampai 2 kali, guru di kelas 3 tersebut menerapkannya kurang lebih 1 tahunan. Dan peserta didik merespon apa yang sudah diajarkan guru kepeserta didik meski ada aja peserta didik yang masih tidak memerhatikan. Peserta didik yang tidak memerhatikan itu salahsatunya peserta didik yang nakal. Guru sudah melakukan semua hal dari menghukum dia di depan kelas sampai dia diserahkan di kesiswaan. Tapi hasilnya tidak ada, peserta didik tersebut tetap nakal. Untuk menanggulangi permasalahan seperti ini guru memisahkan peserta didik nakal dengan peserta didik yang rajin/yang mau diajak belajar bersama. Dari situ peneliti bisa melihat bahwa anak nakal lama kelamaan tidak nyaman dengan perlakuan gurunya terhadap dirinya, akhirnya peserta didik yang nakal tersebut mengikuti proses pembelajaran dengan menggunakan metode Inquiry learning dalam permainan ular tangga.

Disini cara bermain awalnya guru menjelaskan ilmu tauhid tersebut ke peserta didik. Kemudian guru menyuruh peserta didik untuk belajar di rumah agar waktu permainan peserta didik bisa menjawab. Dan waktu itu juga guru membentuk kelompok jadi nanti perkelompok bisa diskusi di lain waktu dan bisa belajar kelompok. Selanjutnya selesai itu semua guru mengumumkan cara bermainnya seperti tidak boleh curang, terus perkelompok harus berkerja kelompok (kompak), dll. Dipermainan tersebut 
ada yang berisi hadiah dan soal. Dalam proses ini peserta didik cukup senang melaksanakan pembelajaran ini.

Selain menjelaskan implementasi metode Inquiry Learning dalam permainan ular tangga, disini peneliti juga menjelaskan tentang tujuan dan respon peserta didik terhadap metode pembelajaran tersebut.

1. Tujuan

Berikut adalah tujuan mengapa diterapkannya metode Inquiry Learning dalam permainan ular tangga. Menurut Muhibatul Islamiyah selaku guru yang menerapkan metode ini tujuannya adalah supaya peserta didik tidak jenuh dalam pelajaran. Dengan ini juga peserta didik bisa belajar cepat.

Sementara itu, menurut Fikki Nadhiroh selaku ketua kelas disitu, dia cukup senang diadakan metode seperti ini karena kalau memaknai kitab terus merasa jenuh dan ditinggal tidur. Dengan adanya metode ini mereka jarang tidur dan mereka semua cukup antusias dengan pembelajaran ini.

2. Respon

Selain tujuan disini ada respon dari peserta didik maupun kepala sekolah. Yang pertama respon dari peserta didik dari perwakilan kelas yaitu Fikki Nadhiroh, dari pernyataan ketua kelas bahwa mereka semua suka dengan pengajaran Muhibatul Islamiyah. Kenapa karena mereka semua lebih gampang menghafal sifat-sifat Allah dan sifatsifat Rasul. dan mempermudah waktu ujian juga.

Yang kedua respon dari kepala sekolah, kepala sekolah pun tidak membatasi guru mau menggunakan metode apa yang terpenting peserta didik memerhatikan penjelasan guru di depan waktu proses mengajar, peserta didik tidak mengantuk, dan peserta didik bisa mengerjakan soal-soal ujian. Memang jadi guru mudah-mudah susah. Tidak semua guru bisa mengayomi peserta didiknya. 


\section{Kelebihan Dan Kelemahan Dalam Metode Inquiry Learning}

Segala sesuatu yang berhubungan dengan manusia pasti tidak jauh dengan kata kelebihan dan kelemahan. Sama dengan kegiatan belajar mengajar yang menggunakan metode Inquiry Learning dalam permainan ular tangga juga memiliki kelebihan dan kelemahan. Berdasarkan hasil wawancara yang peneliti lakukan dengan wali kelas, ketua kelas, dan kepala sekolah tentang apa saja kelabihan dan kelemahan dari Implementasi Metode Inquiry Learning Dalam Permainan Ular Tangga Pada Pelajaran Tauhid Di Kelas 3 Madrasah Diniyah Ponpes Ngalah adalah: pertama Kelebihan dari Implementasi Metode Inquiry Learning Dalam Permainan Ular Tangga Pada Pelajaran Tauhid Di Kelas 3 Madrasah Diniyah Ponpes Ngalah adalah sebagai berikut: peserta didik bisa belajar berpikir kritis dalam memecahkan suatu masalah, peserta didik juga dibelajari tentang hidup yang kompak dan berkeluarga, mempermudah peserta didik untuk mengulang pelajaran yang kemaren diajarkan, menambah wawasan peserta didik. Kedua Kelemahan dari implementasi metode Inquiry Learning dalam permainan ular tangga pada pelajaran tauhid di kelas 3 Madrasah Diniyah Ponpes Ngalah adalah sebagai berikut: peserta didik masih memilih-milih teman kelompoknya masing-masing, kurang kerja kelompoknya, satu dua anak masih tidak mau mengikuti kegiatan belajar mengajar, ada beberapa peserta didik yang tidak bisa menjawab soal yang terdapat dipermainan.

\section{KESIMPULAN}

Berdasarkan hasil penelitian di atas bisa disimpulkan, bahwa Implementasi Metode Inquiry Learning Dalam Permainan Ular Tangga Pada Pelajaran Tauhid Di Kelas 3 Madrasah Diniyah Pondok Pesantren Ngalah itu merupakan sebuah metode dan model pembelajaran yang sudah cukup lama digunakan dalam kelas 3 tersebut. Dengan 
menggunakan metode Inquiry Learning ini anak menjadi semangat dan tidak mengantuk lagi. Menggunakan metode Inquiry Learning ini juga untuk menanggulangi monoton dalam kelas, dimana peserta didik cuma duduk manis di tempatnya tidak memperhatikan guru di depan yang sedang menjelaskan pelajaran. Berikut adalah kelabihan dan kelemahan dari implementasi metode Inquiry Learning dalam permainan ular tangga pada pelajaran tauhid di kelas 3 Madrasah Diniyah Ponpes Ngalah: pertama kelebihan dari implementasi metode Inquiry Learning dalam permainan ular tangga pada pelajaran tauhid di kelas 3 Madrasah Diniyah Ponpes Ngalah adalah sebagai berikut : peserta didik bisa belajar berpikir kritis dalam memecahkan suatu masalah, peserta didik juga dibelajari tentang hidup yang kompak dan berkeluarga, mempermudah peserta didik untuk mengulang pelajaran yang kemaren diajarkan, menambah wawasan peserta didik. Kedua kelemahan dari implementasi metode Inquiry Learning dalam permainan ular tangga pada pelajaran tauhid di kelas 3 Madrasah Diniyah Ponpes Ngalah adalah sebagai berikut : peserta didik masih memilih-milih teman kelompoknya masing-masing, kurang kerja kelompoknya, satu dua anak masih tidak mau mengikuti kegiatan belajar mengajar, ada beberapa peserta didik yang tidak bisa menjawab soal yang terdapat dipermainan.

\section{E. DAFTAR PUSTAKA}

Ahmadi, Rulam. Metodologi penelitian kualitatif, (Yogyakarta: Ar-Ruzz Media, 2016).

Fachrudin Yusuf, Wiwin \& Masruroh Layliyatul. "Metode Permainan Tusuk Kata Dalam Meningkatkan Prestasi Belajar IImu Tajwid Di Madrasah Diniyah Miftahul Ulum Tutur Pasuruan". Vol. 1 No. 2, 2016.

Fachrudin Yusuf, Wiwin \& Nuzulia Firdausi. "Media Limbah Botol Untuk Meningkatkan Pembelajaran PAI Di RA Miftahul Khoir I Karangrejo Purwosari”. Vol. 1 No. 1, 2016. 
Fachrudin Yusuf, Wiwin. "Implementasi Kurikulum 2013 (K-13) Pada Mata

Pelajaran Pendidikan Agama Islam Sekolah Dasar (SD) “. Vol. 3

No. 1, Juni 2018.

Gunawan Imam. Metode Penelitian Kualitatif Teori Dan Praktik, (Jakarta:

PT. Bumi Aksara 2016).

Karim, Abdul. "Peningkatan Hasil Belajar Pada Mata Diklat Menginstalasi

Sistem Operasi Berbasis Gui Menggunakan Metode Inquiry Pada

Siswa Kelas X SMK Negeri 2 Takalar". Vol. 4. No 2, Juli 2016.

Kirom, Askhabul. "Peran Guru Dan Peserta Didik Dalam Proses

Pembelajaran Berbasis Multikultural". Vol. 3 no. 1.

Lestari Tri, Hari Wujoso, Nunuk Suryani, "Pengaruh Metode Pembelajaran

Ceramah Plus Dan Metode Drill Terhadap Motivasi Belajar Dan

Hasil Belajar Pada Kompentensi Dasar Efisiensi Penggunaan

Tempat Tidur Rumah Sakit”. Vol. 7 No. 1, Juni 2017.

Musianto Lukas S. "Perbedaan Pendekatan Kuantitatif Dengan

Pendekatan Kualitatif Dalam Metode Penelitian”. Vol. 4 no. 2.

September 2002.

Nugrahani Rahina, “Media Pembelajaran Berbasis Visual Berbentuk

Permainan Ular Tangga Untuk Meningkatkan Kualitas Belajar

Mengajar Di Sekolah Dasar". Vol. 36. No. 1, Juni 2007.

Rukin. Metodologi Penelitian kualitatif, (Takalar: Yayasan Ahmar Cendekia Indonesia. 2019).

Semiawan Conny R. Metode Penelitian Kualitatif Jenis, Karakteristik Dan

Keunggulannya. (Jakarta: PT Grasindo. 2010).

Sholikhudin M. Anang, Halimatus Sa'diyah, "Model Pengelolaan Kelas

Dalam Pembelajaran PAI Di SD Riyadlul Arkham Tembong

Plintahan Pandaan”. Vol. 2. No. 2, Juni 2017, hal. 293

Sugiharto, Dkk, "Psikologi Pendidikan”. Yogyakarta: Uny Press.

Sugiyono. Metode penelitian administrasi. (Yogyakarta: LkiS 2008).

Syamsidah, Ratnawati. Panduan model inquiry learning (Yogyakarta: CV

BUDI UTAMA 2020).

Widowati, Febryna, Mulyani. "Penggunaan Media Ular Tangga Untuk Meningkatkan Hasil Belajar Siswa Pada Tema Hiburan”. Vol. 02. No. 01, 2014. 